\title{
ANTIFUNGAL ACTIVITIES OF THIOSEMICARBAZONES AND SEMICARBAZONES AGAINST MYCOTOXIGENIC FUNGI
}

\author{
Atividade antifúngica de tiosemicarbazonas e semicarbazonas \\ frente a fungos micotoxigênicos
}

\author{
Rojane de Oliveira Paiva ${ }^{1}$, Lucimar Ferreira Kneipp ${ }^{2}$, Carla Marins Goular ${ }^{1}$, \\ Mariana Almeida Albuquerque ${ }^{1}$, Aurea Echevarria ${ }^{3}$
}

\begin{abstract}
Mycotoxigenic fungi can compromise the quality of food, exposing human and animal health at risk. The antifungal activity of eight thiosemicarbazones (1-8) and nine semicarbazones (9-17) was evaluated against Aspergillus flavus, A. nomius, A. ochraceus, A. parasiticus and Fusarium verticillioides. Thiosemicarbazones had MIC values of 125-500 $\mu \mathrm{g} / \mathrm{ml}$. The thiosemicarbazones 1 and 2 exerted fungistatic activity against Aspergillus spp., and thiosemicarbazone 2 exerted fungicidal activity against $F$. verticillioides. Compound 2 showed an iron chelating effect of $63 \%$. The ergosterol content of $A$. parasiticus had a decrease of 28 and $71 \%$ for the 31.2 and $62.5 \mu \mathrm{g} / \mathrm{ml}$ concentrations of thiosemicarbazone 2 compared to the control. The obtained results of antifungal activity revealed that thiosemicarbazone class was more active when compared to semicarbazone class and, the thiosemicarbazone 2 was the most active compound, specially, against Aspergillus spp.
\end{abstract}

Index terms: Aspergillus, Fusarium, mycotoxicology, thiosemicarbazones.

\section{RESUMO}

Os fungos micotoxigênicos podem comprometer a qualidade dos alimentos colocando em risco a saúde do homem e dos animais. As atividades antifúngicas de oito tiosemicarbazonas (1-8) e nove semicarbazonas (9-17) foram avaliadas frente Aspergillus flavus, A. nomius, A. ochraceus, A. parasiticus e Fusarium verticillioides. As tiosemicarbazonas apresentaram valores de MIC entre 125 a $500 \mu \mathrm{g} / \mathrm{ml}$. As tiosemicarbazonas 1 e 2 exerceram atividade fungistática frente Aspergillus spp., e enquanto, a substância 2 apresentou atividade fungicida frente $F$. verticillioides. O composto 2 também foi capaz de apresentar efeito quelante (63\%) frente ao ferro e, reduzir 28 e $71 \%$ o conteúdo de ergosterol de $A$. parasiticus nas concentrações de 31,2 e $62,5 \mu \mathrm{g} / \mathrm{ml}$, respectivamente. Os resultados obtidos para a atividade antifúngica revelaram que a classe das tiossemicarbazonas foi mais ativa quando comparada a classe das semicarbazones e, a tiossemicarbazona 2 foi mais ativa frente Aspergillus spp.

Termos para indexação: Aspergillus, Fusarium, micotoxicologia, tiosemicarbazonas.

\section{INTRODUCTION}

Thiosemicarbazones (TS) and semicarbazones (SM) are a class with widespread biological activities including antiviral (Banerjee et al., 2011), antitumor (Easmon et al., 2001), antiparasitic (Oliveira et al., 2008) and antifungal (Tenório et al., 2005) activities. These compounds are able to complex with metal ions, and their biological activity is modulated by the structure of the ligand and the nature of the metal (Pelosi, 2010). Several papers described the antifungal activities of thiosemicarbazones complex, including the Aspergillus spp. (Al-Amiery et al., 2012) and thiosemicarbazones as free ligands detaching A. parasiticus, Candida albicans, A. niger, Trichophyton mentagrophites, Rizocthonia solani and Stemphylium solani (Reis et al., 2011; Brousse et al., 2004).

Some strategies are used to minimize the loss of food and other agricultural commodities (Palencia et al., 2010, Medeiros et al., 2012). Benzoic, ascorbic, propionic, formic and acetic acids are used to prevent food contamination. However, the intensive use of these compounds can enhance the expression of mycotoxins by toxigenic fungi, such as aflatoxin (Katerere et al., 2008). Several papers described the antifungal activities of thiosemicarbazones complex, including the Aspergillus spp. (Aljahdali; El-Sherif, 2013; Alomar et al., 2013), and thiosemicarbazones as free ligands detaching A. parasiticus, Candida albicans and A. niger (Al-Amiery et al., 2012; Reis et al., 2011; Kizilcikli et al., 2007). Further, this class of molecules presents no significant toxicity to the macrophage cells (Soares et al., 2011). Aspergillus and Fusarium genera encompass species with mycotoxigenic potential and are found in food and feed (Sundheim et al., 2013).

In this work, the antifungal activities of eight thiosemicarbazones (1-8) and nine semicarbazones (9-17) were evaluated against Aspergillus spp. and Fusarium

\footnotetext{
1Universidade Federal Rural do Rio de Janeiro/UFRRJ - Departamento de Química - Seropédica - RJ - Brasil

${ }^{2}$ Instituto Oswaldo Cruz/FIOCRUZ - Rio de Janeiro - RJ - Brasil

3Universidade Federal Rural do Rio de Janeiro/UFRRJ - Departamento de Química - Seropédica - RJ - Brasil - echevarr@ufrij.br

Received in june 9, 2014 and approved in october 26, 2014
} 
verticillioides. For compounds with antifungal activity, the $\mathrm{Fe}^{2+}$ chelating effect was evaluated, and their ability to alter fungal ergosterol levels was evaluated by HPTLC method.

\section{MATERIALS AND METHODS}

\section{Preparation of synthetic substances}

Thiosemicarbazones were synthesized using the appropriate aldehydes and thiosemicarbazide, with drops of concentrated sulfuric and ethanol as a solvent, as previously described in the literature (Oliveira et al., 2008). Semicarbazones were prepared using aldehydes and semicarbazide hydrochloride in the presence of sodium acetate, with ethanol as a solvent (Guerra et al., 2006). All products were characterized by infrared, mass, ${ }^{1} \mathrm{H}$ and ${ }^{13} \mathrm{C}$ NMR spectroscopies.

The compounds were solubilized in DMSO (Merck, Darmstad, Germany): Tween ${ }^{\circledR} 20$ (Merck, Darmstad, Germany): RPMI 1640 (Invitrogen, USA) diluted in the ratio $1: 1: 8$. The culture medium RPMI 1640 , containing L-glutamine without sodium bicarbonate, was buffered with 3-( $N$-morpholino) propanesulfonic acid (MOPS) (Merck, Darmstad, Germany) at a final concentration of $0.165 \mathrm{~mol} / \mathrm{l}$, and $\mathrm{pH}$ 7.0.

\section{Antifungal activity assays}

All fungal strains were obtained from the Mycological Collection Trichocomaceae of the Oswaldo Cruz Institute-Fiocruz/RJ. Aspergillus flavus MCT 00040, A. nomius MCT 00328, A. ochraceus MCT 00435, A. parasiticus MCT 00334, and Fusarium verticillioides MCT 00177 were rehydrated and activated in Sabouraud dextrose agar (SDA) culture medium and incubated for seven days at $25^{\circ} \mathrm{C}$. To induce conidia formation, cultures were grown in potato dextrose agar (PDA) medium for seven days at $35^{\circ}$ C. A. ochraceus was incubated for seven days at $25^{\circ} \mathrm{C}$, and $F$. verticillioides was maintained at $35^{\circ} \mathrm{C}$ for $48 \mathrm{~h}$ and then incubated at $25^{\circ} \mathrm{C}$ until day seven.

\section{Minimal inhibitory concentrations (MIC) and IC $_{50}$ determination}

Antifungal susceptibility testing was performed as described in the M38-A document for filamentous fungi (CLSI, 2002) using 96-well microtiter assay plates containing RPMI 1640 medium at $\mathrm{pH} 7.0$ buffered with MOPS. The compounds were diluted to obtain final concentrations ranging from 3.9 to $500 \mu \mathrm{g} / \mathrm{ml}$, and the maximum concentration of DMSO was $2.5 \%$ (v/v). Conidia of Aspergillus spp. and F. verticillioides were inoculated into the appropriate wells at a final concentration of $0.4-5 \times 10^{4} \mathrm{CFU} / \mathrm{ml}$. Control wells were inoculated with fungi without (solvent and medium alone) the addition of antifungal compounds. Solvent and medium alone were also prepared to be used as control. The minimum inhibitory concentration (MIC) of each drug was determined visually after incubation at $35^{\circ} \mathrm{C}$ for $48 \mathrm{~h}$. The MIC was accepted as the lowest concentration of the substance able to completely inhibit $(100 \%)$ the visible growth of the fungus. Amphotericin B (AMB) (Sigma Chemical Co., Missouri, USA) was used as a reference at final concentrations ranging from 16 to $0.12 \mu \mathrm{g} / \mathrm{ml}$. Each experiment was performed in triplicate. The half maximal inhibitory concentration $\left(\mathrm{IC}_{50}\right)$ values were determined for thiosemicarbazones 1 and 2 using the same microplate assays. Data processing and calculation of the $\mathrm{IC}_{50}$ values were performed in Excel 2007 (Microsoft Co., Redmond, WA) after doseresponse curve determination. The antifungal activity (AA) was calculated by applying expression (1) to absorbance values obtained at 490nm (Ueda-Nakamura et al., 2006).

$\operatorname{AA}(\%)=100-\left(\frac{\left(\mathrm{A}_{\text {sample }}-\mathrm{A}_{\text {mean of growth inhibition }}\right)}{\left(\mathrm{A}_{\text {mean of } 100 \% \text { growth }}-\mathrm{A}_{\text {mean of } 100 \% \text { growth inhibition }}\right)}\right) \times 100$

\section{Minimal fungicidal concentration (MFC) determination}

To determine the minimal fungicidal concentration (MFC) the contents of each well were homogenized and an aliquot $(1 \mu \mathrm{l})$ from each well was transferred onto SDA. The plates were incubated at $30^{\circ} \mathrm{C}$ for nine days. The MFC was defined as the lowest concentration without visible growth of fungal colonies. The fungicidal effect was considered when the values of the MFC was less than or equal to four times the MIC value, as described by Pfaller et al. (2004).

\section{Determination of iron chelating activity}

To assess the $\mathrm{Fe}^{2+}$ chelating activity, solutions containing 1 an $2(3.75 \mu \mathrm{M})$ in distilled water: DMSO $(3: 1,5.0 \mathrm{ml})$ were used. $\mathrm{FeSO}_{4}(3.75 \mu \mathrm{M})$ in distilled water was added to each solution. Spectrophotometric determinations, scanning interval of $190-500 \mathrm{~nm}$, were obtained using a UV-Vis spectrophotometer (Shimadzu UV-Vis Mini 1240) and a quartz cuvette $(1.7 \mathrm{ml})$. The ability of the samples to chelate $\mathrm{Fe}^{2+}$ ions was calculated using equation 2 and expressed as a percentage (Lim et al., 2009). 


$$
\text { Chelating effect }(\%)=-\left[1-\left(A_{\text {sample }} / A_{\text {control }}\right)\right] \times 100 \%
$$

\section{Determination of the stoichiometry of the thiosemicarbazone $-\mathrm{Fe}^{2+}$ complex}

To determine the stoichiometry of the thiosemicarbazone-Fe ${ }^{2+}$ complex, the L-M Mollard Method was used, with $\mathrm{Fe}^{2+}$ ranging from 25 to $225 \mu \mathrm{M}$ and thiosemicarbazones ranging from 225 to $25 \mu \mathrm{M}$, according to equation 3 (Guerra et al., 2006; Farias, 2009).

$$
l / m=C_{l} x A_{m} / C_{m} x A_{l}
$$

$\mathrm{l} / \mathrm{m}=$ ratio between metal and ligand concentrations; $\mathrm{C}_{1}$ = ligand concentration; $\mathrm{C}_{\mathrm{m}}=$ metal concentration; $\mathrm{A}_{1}=$ ligand absorbance; $\mathrm{A}_{\mathrm{m}}=$ metal absorbance

\section{Ergosterol extraction and evaluation by high performance thin-layer chromatography}

A. parasiticus conidia $\left(1 \times 10^{7} / \mathrm{ml}\right)$ were incubated at $26^{\circ} \mathrm{C}$ in RPMI medium in the presence or absence (control) of sub-inhibitory concentrations of antifungal compounds (i.e., 125 and $250 \mu \mathrm{g} / \mathrm{ml}$ of 1 , and 31.2 and $62.5 \mu \mathrm{g} / \mathrm{ml}$ of 2). After $48 \mathrm{~h}$, conidia were harvested by centrifugation and washed 3 times with $0.85 \% \mathrm{NaCl}$. Total lipids were extracted using chloroform: methanol (2:1; 1:1; and 1:2) mixtures (Soares et al., 1995). Combined extracts were dried under a stream of nitrogen and submitted to Folch partition (Folch et al., 1957). The lower phase (neutral lipids) was dried, resolubilized in chloroform and subjected to high performance thinlayer chromatography (HPTLC). The chromatography was carried out on silica gel 60 plates (Sigma Chemical Co., Missouri, USA) using hexane:diethyl ether:acetic acid $(60: 30: 1.5)$ as a solvent, and the spots were visualized by dipping the plate in a chemical reagent $(50$ $\mathrm{mg}$ of iron chloride, $5 \mathrm{ml}$ of acetic acid, $5 \mathrm{ml}$ of sulfuric acid and $90 \mathrm{ml}$ of distilled water) for $2 \mathrm{~s}$ followed by heating (Larsen et al., 2004). Ergosterol $(4 \mu \mathrm{g})$ and lanosterol $(1 \mu \mathrm{g})$ purchased from Sigma Chemical Co. (Missouri, USA) were also subjected to HPTLC and were used as standards for sterols. Densitometric quantification of ergosterol was performed using Image $\mathrm{J}$ free software (Cabral et al., 2013). This experiment was performed three times, obtained from independent triplicate culture/extraction. Compounds concentrations used in this experiment not affected the viability of $A$. parasiticus conidia.

\section{RESULTS AND DISCUSSION}

The thiosemicarbazones (1-8) were synthesized from appropriate aldehydes and thiosemicarbazide under acid catalysis as previously described (Oliveira et al., 2008), and the semicarbazones (9-17) from aldehydes, semicarbazide hydrochloride and sodium acetate in ethanol as a solvent (Guerra et al., 2006) (Figure 1). The thiosemicarbazones were obtained with $60-95 \%$ yield and the semicarbazones with $45-95 \%$ yield.
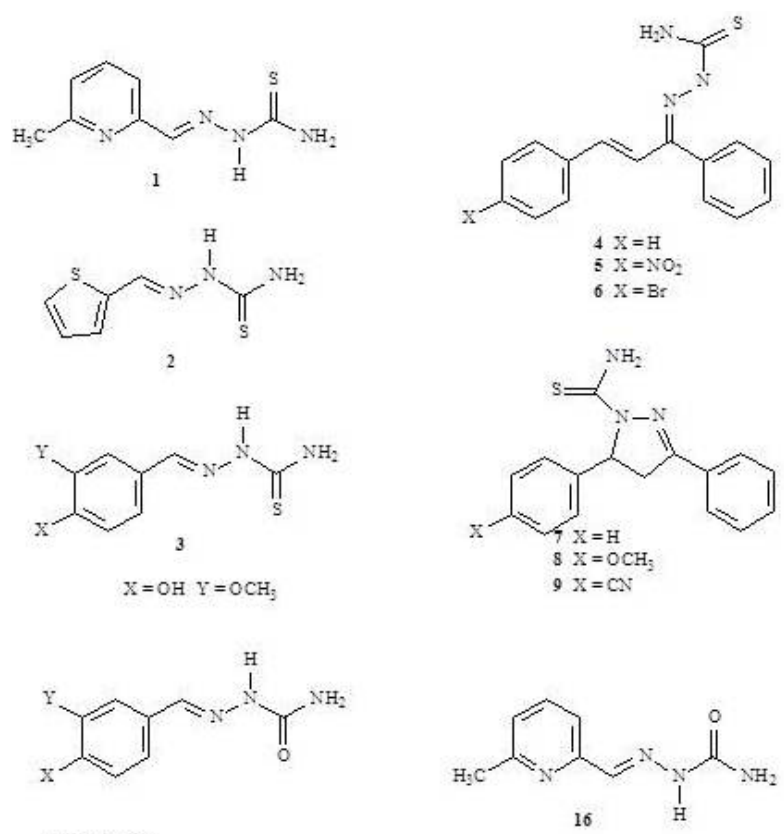

$10 \mathrm{X}=\mathrm{Y}=\mathrm{H}$

$11 \mathrm{X}=\mathrm{NO}_{2} \mathrm{Y}=\mathrm{H}$

$12 \mathrm{X}=\mathrm{Cl} \mathrm{Y}=\mathrm{H}$

$14 \mathrm{X}=\mathrm{OH} \mathrm{Y}=\mathrm{OCH}$

$15 \mathrm{X}=\mathrm{Br} \mathrm{Y}=\mathrm{H}$

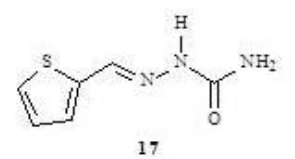

Figure 1 - Chemical structures of the synthesized thiosemicarbazones and semicarbazones.

Thiosemicarbazones 1-9 and semicarbazones 10-17 were assayed against Aspergillus spp. and F. verticillioides using the broth microdilution method (CLSI, 2002). The results indicated that thiosemicarbazone class is more effective at inhibiting fungal growth than those of the semicarbazone class. Thiosemicarbazone 2 inhibited the growth of all fungal samples with an MIC of $125 \mu \mathrm{g} / \mathrm{ml}$ against $\mathrm{A}$. nomius, $\mathrm{A}$. ochraceus and $\mathrm{A}$. parasiticus and with MICs of $250 \mu \mathrm{g} / \mathrm{ml}$ and $500 \mu \mathrm{g} / \mathrm{ml}$ against A. flavus and F. verticillioides, respectively. Thiosemicarbazone 1 inhibited 
$100 \%$ of fungal growth at a concentration of $500 \mu \mathrm{g} / \mathrm{ml}$ for A. flavus, A. parasiticus and $F$. verticillioides. The fungus most sensitive to the action of the thiosemicarbazones was $A$. parasiticus; thiosemicarbazone 2 showed the best inhibitory activity $(\mathrm{MIC}=125 \mu \mathrm{g} / \mathrm{ml})$ against this strain, while thiosemicarbazones $1,3,4,5$, and 6 had MICs of $500 \mu \mathrm{g} / \mathrm{ml}$. The second most sensitive fungus to the thiosemicarbazones was A. flavus. Semicarbazones 9 and 11 showed weak growth inhibition only against A. flavus and $F$. verticillioides. AMB was used as a reference standard and had an MIC of $2 \mu \mathrm{g} / \mathrm{ml}$ for most Aspergillus species and for $F$. verticillioides.

The obtained results for aromatic ketone thiosemicarbazone derivatives showed MIC values $128 \mathrm{mg} / \mathrm{ml}$ against $A$. niger (Brousse et al., 2004). The thiosemicarbazones $S$-methyl substituted and their zinc complex showed antifungal activity against Candida albicans with MIC values in the range of 19.5 and 312 $\mathrm{mg} / \mathrm{l}$, respectively (Kizilcikli et al., 2007), and our previous results for $N_{l}, N_{4}$-disubstituted thiosemicarbazones presented against $C$. albicans MIC values of $250 \mu \mathrm{g} /$ $\mathrm{ml}$ (Reis et al., 2011). Thus, the results obtained for thiosemicarbazone 2 with MIC values of $125 \mu \mathrm{g} / \mathrm{ml}$ against A. nomius, A. ochraceus and A. parasiticus are in the same range of antifungal activity described in the literature.

After the MIC values were determined for thiosemicarbazones 1 and 2, the same microplates were evaluated in turbidity assays using an Elisa reader (490 $\mathrm{nm}$ ), and the $\mathrm{IC}_{50}$ values were calculated to be $86.5 \mu \mathrm{g} / \mathrm{ml}$ and $66.7 \mu \mathrm{g} / \mathrm{ml}$ for 1 and 2 , respectively.

The antifungal activities of the thiosemicarbazones and semicarbazones were evaluated against all mycotoxigenic fungi. However, only the compound 2 had fungicidal effect (MFC $500 \mu \mathrm{g} / \mathrm{ml}$ ) against $F$. verticillioides, as seen in figure 2 .

The results suggested that heterocyclic thiosemicarbazone derivatives (compounds 1 and 2) have increased antifungal activity. When compared the results of the thiosemicarbazone 2 and the semicarbazone 17 results, both thiophene derivatives, is shown the importance of the sulphur instead oxygen atom affording to greatest antifungal activity. Further, when compared our result with other thiosemicarbazone as free ligand, in general way, can be observed MIC values in the same range (Serda et al., 2012). Generally, food and feed commodities are naturally contaminated with mycotoxin-producing fungi, and the antifungal activity of thiosemicarbazones, as ligand free, studied in this work against Aspergillus flavus, A. nomius, A. ochraceus, A. parasiticus and Fusarium verticillioides, revealed a new control alternative.

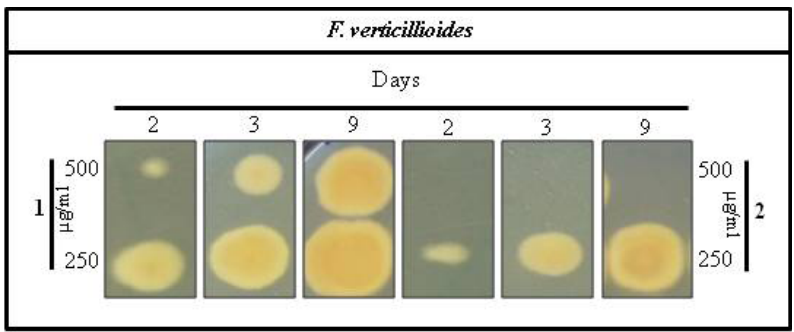

Figure 2 - Minimum fungicidal concentrations (MFCs) of thiosemicarbazones 1 and 2 against Fusarium verticillioides. Conidia were added to 96 -well microtiter plates containing RPMI 1640 medium, $\mathrm{pH} 7.0$, and 500 or $250 \mu \mathrm{g} / \mathrm{ml}$ of thiosemicarbazones 1 and 2 . After a 48 $\mathrm{h}$ incubation at $35^{\circ} \mathrm{C}$ and MIC determination, each well was homogenized, and an aliquot $(1 \mu \mathrm{l})$ was added to SDA medium. After incubation at $35^{\circ} \mathrm{C}$ for 2,3 and 9 days, the MFC was determined as the lowest concentration without visible growth of fungal colonies.

The metal chelating activity of thiosemicarbazones is well known (Beraldo, 2004). Iron plays an important role in many essential biological processes (Tenório et al., 2005). Thiosemicarbazones inactivate the non-heme iron subunits of several iron-dependent enzymes, such as the ribonucleotide reductase, a key enzyme for fungal survival (Soares et al., 2011). Thus, thiosemicarbazones 1 and 2 were evaluated for $\mathrm{Fe}^{2+}$ chelating activity using UV-visible spectroscopy (Soares et al., 1995). Figure 3 shows the superimposed spectra of thiosemicarbazones 1 and 2 in the presence and absence of $\mathrm{Fe}^{2+}$, and a chelating effect is indicated by increased absorbance. The observed chelating effects of $63 \%$ for thiosemicarbazone 2 and $6 \%$ for thiosemicarbazone 1 correlated with the observed antifungal activities and suggested a possible mechanism of action for the thiosemicarbazones. The $\mathrm{Fe}^{2+}$ coordination number was also determined using the method of Mollard, which indicated a value of 3 for the two thiosemicarbazones with planar pyramidal geometry. These results indicated that the thiosemicarbazones act as dinuclear ligands and share two molecules (French; Blanzy, 1966), and iron chelating effect by antifungal drugs may be useful for prevention and treatment of fungal infections (Zarember et al., 2009).

The ergosterol is an important membrane sterol essential for fungal growth, such as for membrane fluidity and cellular cycle regulation. The mechanism of action of antifungal agents may involve changes in sterol biosynthesis that reduce the amount of 
ergosterol produced by the fungus (Alcazar-Fuoli; Mellado, 2013). Synthetic substances can also form complexes with ergosterol and disrupt the fungal plasma membrane, resulting in increased membrane permeability, leakage of cytoplasmic contents and, ultimately, death of the fungal cell (Kathiravan et al., 2012).
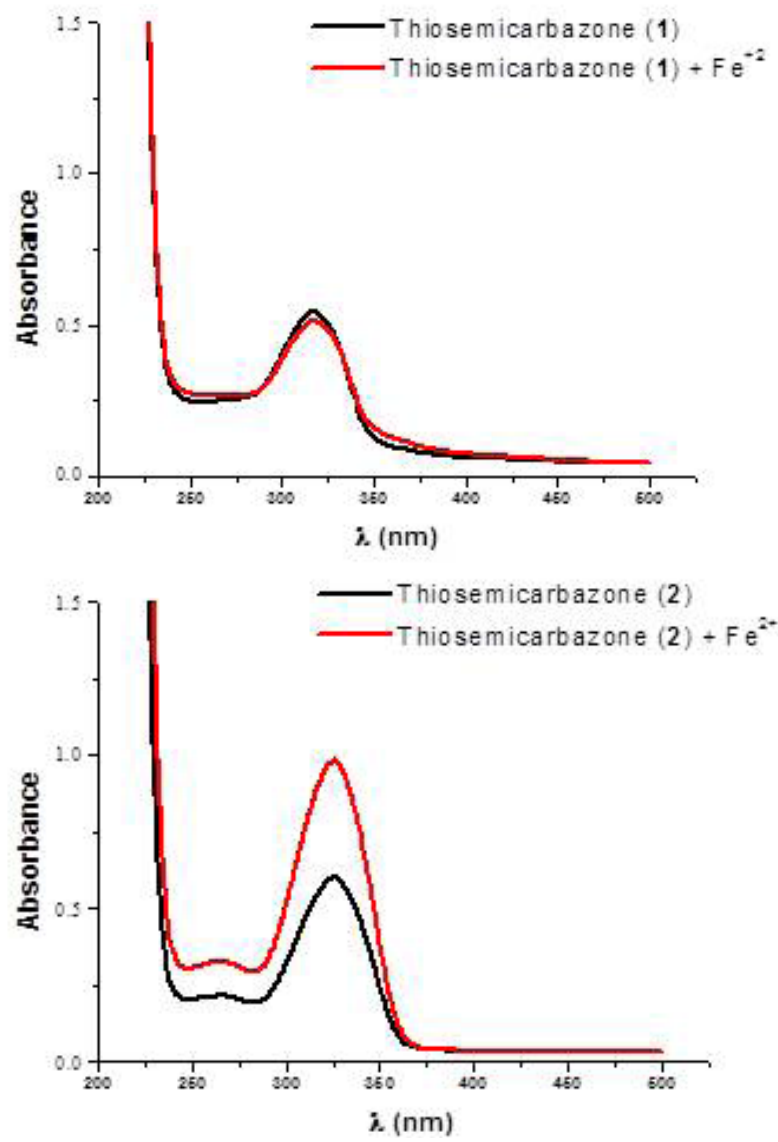

Figure 3 - Superimposed UV-visible spectra of thiosemicarbazone $1(30 \mu \mathrm{M})$ in the absence and presence of $\mathrm{Fe}^{2+}(3.75 \mu \mathrm{M})$. Superimposed UV-visible spectra of thiosemicarbazone $2(30 \mu \mathrm{M})$ in the absence and presence of $\mathrm{Fe}^{2+}(3.75 \mu \mathrm{M})$.

The treatment with $250 \mu \mathrm{g} / \mathrm{ml}$ of thiosemicarbazone 1 decreased A. parasiticus ergosterol content to approximately $33 \%$ of that of untreated conidia, while thiosemicarbazone 2 reduced fungal ergosterol content to $28 \%$ and $71 \%$ at 31.2 and $62.5 \mu \mathrm{g} /$ $\mathrm{ml}$, respectively, indicating a dose-dependent response (Figure 4).

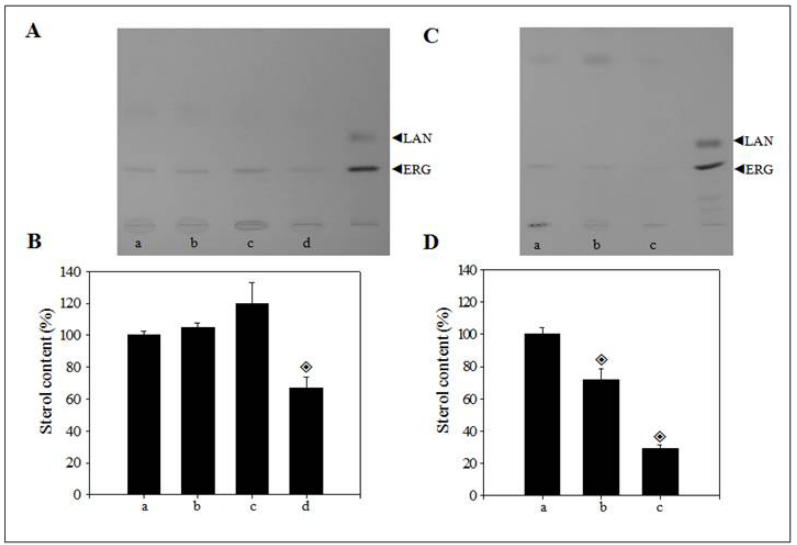

Figure 4 - Effect of thiosemicarbazones 1 and 2 on ergosterol production by $A$. parasiticus. (A) Conidia were incubated at $26^{\circ} \mathrm{C}$ for $48 \mathrm{~h}$ in RPMI 1640 medium in the absence (a) or presence of $125 \mu \mathrm{g} / \mathrm{ml}$ (c) and $250 \mu \mathrm{g} / \mathrm{mL}$ (d) thiosemicarbazone 1 (A) and of $31.2 \mu \mathrm{g} / \mathrm{ml}$ (b) and $62.5 \mu \mathrm{g} / \mathrm{ml}$ (c) thiosemicarbazone 2 (C). The ergosterol (ERG) and lanosterol (LAN) standards were also applied to HPTLC plates, as indicated by arrows. The use of $1 \%$ DMSO as an eluent for the thiosemicarbazones did not alter ergosterol levels (b, panel A). Densitometric quantifications (B and D) correspond to each plate above. Graphical representation of HPTLC data was analyzed by means of the Image J software. Sterols content referred to the control was taken as $100 \%$. Symbols denote significant differences $(\diamond, \mathrm{P}<0.05$ Student's $\mathrm{t}$ test) in comparison with control cells (no treatment).

\section{CONCLUSIONS}

The obtained results of antifungal activity revealed that thiosemicarbazone class was more active specially, against Aspergillus spp. and showed chelating effect and decreased the ergosterol in lipidic content. Further, the compound 2 showed fungicidal effect against $F$. verticillioides.

\section{ACKNOWLEDGMENTS}

The authors thank Conselho Nacional de Desenvolvimento Científico e Tecnológico (CNPq), Fundação de Amparo a Pesquisa do Estado do Rio de Janeiro (FAPERJ) and the Coordenação de Aperfeiçoamento de Pessoal de Nível Superior (CAPES) for financial support and fellowships. The authors also thank the Mycological Collection Trichocomaceae of the Oswaldo Cruz Institute - Fiocruz/RJ for providing fungal strains. 


\section{REFERENCES}

ALCAZAR-FUOLI, L.; MELLADO, E. Ergosterol biosyntesis in Aspergillus fumigatus: its relevance as an antifungal target and role in antifungal drug resistance. Frontiers in Microbiology, 3:1-6, 2013.

ALJAHDALI, M.; EL-SHERIF, A.A. Synthesis, characterization, molecular modeling and biological activity of mixed ligand complexes of $\mathrm{Cu}(\mathrm{II}), \mathrm{Ni}(\mathrm{II})$ and $C o(I I)$ based on 1,10-phenanthroline and novel thiosemicarbazone. Inorganic Chimica Acta, 4075840768, 2013.

ALOMAR, K. et al. Synthesis, structure and antifungal activity of thiophene-2,3-dicarboxaldehyde bis (thiosemicarbazone) and nickel (II), copper (II) and cadmium (II) complexes: Unsymmetrical coordination mode of nickel complex. Journal of Inorganic Biochemistry, 126:76-83, 2013.

AL-AMIERY, A.A.; KADHUM, A.A.H.; MOHAMAD, A.B. Antifungal and antioxidant activities of pyrrolidone thiosemicarbazone complexes. Bioinorganic Chemistry and Applications, 1-6, 2012.

BANERJEE, D. et al. Novel isatinyl hiosemicarbazones derivatives as potential molecule to combat HIV-TB coinfection. European Journal of Medicinal Chemistry, 46(1):106-121, 2011.

BERALDO, H. Semicarbazonas e tiossemicarbazonas: o amplo perfil farmacológico e usos clínicos. Química Nova, 27(3):461-471, 2004.

BROUSSE, B.N. et al. Antibacterial and antifungal activity of some thiosemicarbazones and 1,3,4-thiadiazolines. Journal of the Chilean Chemical Society, 49(1):45-49, 2004.

CABRAL, M.E.; FIGUERO, LIC.; FARIÑA, J.I. Synergistic antifungal activity of statin-azole associations as witnessed by Saccharomyces cerevisiae and Candida utilis bioassays and ergosterol quantification. Revista Iberoamericana de Micologia, 30(1):31-38, 2013.

Clinical Laboratory Standards-CLSI. Reference Method for Broth Dilution Antifungal Susceptibility
Testing of Conidium-Forming Filamentous Fungi: Approved Standard M38-A: CLSI: Wayne, PA, USA, 22-32, 2002.

EASMON, J. et al. Synthesis, cytotoxicity, and antitumor activity of Copper(II) and Iron(II) complexes of ${ }^{4} N$-azabicyclo[3.2.2] nonane thiosemicarbazones derived from acyl diazines. Journal of Medicinal Chemistry, 44(13):2164-2171, 2001.

FARIAS, R.F. Em química de coordenação: fundamentos e atualidades. Farias RF, editor; Campinas: Átomo. 424p., 2009.

FRENCH, F.A.; BLANZY, JR.E.J. The carcinostatic activity of thiosemicarbazones of formyl heteroaromatic compounds. III. Primary correlation. Journal of Medicinal Chemistry, 9(4):585-589, 1966.

FOLCH, A.J.; LEES, M.; STANLEY, G.H.S. A simple method for the isolation and purification of total lipids from animal tissues. Journal of Biological Chemistry, 226(1):497-509, 1957.

GUERRA, W. et al. Síntese e caracterização de complexos de platina (II) contendo iodeto e derivados do furano como ligantes. Eclética Química, 31(1):3944, 2006.

KATERERE, D.R.; SHEPHARD, G.S.; FABER, M. Infant malnutrition and chronic aflatoxicosis in Southern Africa: is there a link? International Journal of Food Safety, Nutrition and Public Health, 1:126-136, 2008.

KATHIRAVAN, M.K. et al. The biology and chemistry of antifungal agents: A review. Bioorganic Medicinal Chemistry, 20(19):5678-5698, 2012.

KIZILCIKLI, I. et al. Antimicrobial activity of a series of thiosemicarbazones and their $\mathrm{Zn}$ (II) and $\mathrm{Pd}$ (II) complexes. Folia Microbiology, 52(1):15-25, 2007.

LARSEN, T.; AXELSEN, J.; RAVN, H.W. Simplified and rapid method for extraction of ergosterol from natural samples and detection with quantitative and semi-quantitative methods using thin-layer chromatography. Journal of Chromatografy A, 1026(1-2):301-304, 2004.

Ciênc. Agrotec., Lavras, v.38, n.6, p.531-537, nov./dez., 2014 
LIM, T.Y.; LIM, Y.Y.; YULE, C.M. Evaluation of antioxidant, antibacterial and anti-tyrosinase activities of four Macaranga species. Food Chemistry, 114(2):594599, 2009.

MEDEIROS, F.H.V. de et al. Biological control of mycotoxin-producing molds. Ciência e Agrotecnologia, 36(5):483-497, 2012.

OLIVEIRA, R.B. et al. Synthesis and antimalarial activity of semicarbazone and thiosemicarbazone derivatives. European Journal of Medicinal Chemistry, 43(9):1983-1988, 2008.

PALENCIA, E.R.; HINTON, D.M.; BACON, C.W. The black Aspergillus species of maize and peanuts and their potential for mycotoxin production. Toxins, 2(4):399416, 2010.

PELOSI, G. Thiosemicarbazone metal complex: From structure to activity. The Open Crystal Journal, 3:1628,2010 .

PFALLER, M.A, SHEEHAN, D.J, REX, J.H. Determination of fungicidal activities against yeasts and molds: Lessons learned from bactericidal testing and the need for standardization. Clinical Microbiology Reviews, 17(2):268-280, 2004.

REIS, C.M. et al. Microwave-assisted synthesis of new $N_{1}, N_{4}$-substituted thiosemicarbazones. Molecules, 16:10668-10684, 2011.
SERDA, M. et al. Investigation of the biological properties of (hetero)aromatic thiosemicarbazones.

Molecules, 17(11):13483-13502, 2012.

SOARES, R.M.A. et al. Carbohydrate and lipid components of hyphae and conidia of human pathogen

Fonsecaea pedrosoi. Mycopathologia, 132(2):71-77, 1995.

SOARES, R.O.A. et al. Evaluation of thiosemicarbazones and semicarbazones as potential agents anti-Trypanosoma cruzi. Experimental

Parasitology, 129(4):381-387, 2011.

SUNDHEIM, L.; HOFGAARD, I.S.; RAFOOS, T. Temporal variation of mycotoxin producing fungi in Norwegian cereals. Microorganisms, 1(1):188-198, 2013.

TENÓRIO, R.P. et al. Tiossemicarbazonas: métodos de obtenção, aplicações sintéticas e importância biológica. Química Nova, 28(6):1030-1037, 2005.

UEDA-NAKAMURA, T. et al. Antileishmanial activity of Eugenol-rich essential oil from Ocimum gratissimum. Parasitology International, 55(2):99-105, 2006.

ZAREMBER, K.A. et al. Antifungal activities of natural and synthetic iron chelators alone and in combination with azole and polyene antibiotics against Aspergillus fumigatus. Antimicrobial Agents Chemotherapy, 53(6):2654-2656, 2009. 